\title{
GRIPE A, UMA NOVA "ESPANHOLA"?
}

Desde abril, muitos brasileiros têm acompanhado com curiosidade e preocupação notícias sobre uma nova epidemia de gripe, denominada primeiro de gripe suína e depois de gripe A (H1N1). Muitas são as dúvidas da população. Seria possível uma gripe tornar-se moléstia fatal para um grande número de pessoas? Quais os meios para evitar a doença? Qual o tratamento adequado para prevenir e liquidar a enfermidade? As questões feitas em 2009, e várias das respostas dos médicos a estas perguntas, parecem ecos das falas de leigos e doutores que viveram em 1918, quando a devastadora epidemia de gripe espanhola ou influenza espanhola vitimou o planeta.

Apesar do nome pelo qual ficou conhecida, "espanhola", a gripe de 1918 teria surgido em campos de treinamento militar nos Estados Unidos e se espalhado pelo mundo em consequência do movimento de tropas que lutavam na Primeira Guerra Mundial. A Espanha, país neutro durante a guerra, não censurava as notícias sobre a nova epidemia, daí alguns deduzirem, equivocadamente, que a moléstia tivesse origem ou fizesse mais vítimas no país. Com exceção de algumas ilhas da Oceania, totalmente isoladas, o ciclo letal da influenza espanhola varreu o mundo entre agosto de 1918 e janeiro de $1919^{1}$.

No Brasil, a gripe espanhola mobilizou a atenção de médicos, governo e população em geral a partir de setembro de 1918, depois que brasileiros contraíram a doença na África. Vários morreram. Esses homens eram membros da Missão Médica Brasileira e soldados do exército nacional, cujos navios ancoraram em Dakar (Senegal) e em Freetown (Serra Leoa) na primeira semana de setembro, antes de seguirem para a Europa em guerra. Notícias sobre os acontecimentos na África foram publicadas em diversos jornais nacionais e, nesses mesmos periódicos, artigos informavam sobre a passagem pelo Brasil do navio Demerara que, vindo da Europa, havia aportado nas cidades de Recife, Salvador e Rio de Janeiro com doentes a bordo. No final de setembro, informações sobre gripados nas cidades portuárias começaram a ser divulgadas em todo o país e, em poucos dias, a moléstia fazia vítimas também nas cidades do interior do Brasil2

O cotidiano dos brasileiros foi drasticamente modificado devido à epidemia, e as instruções divulgadas para o combate à gripe espanhola eram muito semelhantes aos conselhos médico-governamentais veiculados atualmente pelas televisões, rádios, jornais e internet para tentar impedir a difusão da gripe $\mathrm{A}$. Medidas similares às implementadas na Cidade do México, em 2009, também foram realizadas em cidades de todo o mundo, na tentativa de evitar a propagação da influenza espanhola.

Em 1918, com a confirmação dos primeiros casos de gripe epidêmica no Brasil, ações governamentais foram efetuadas para cuidar dos doentes e socorrer os familiares dos gripados mais pobres (destaque para os postos de socorro e hospitais provisórios) e os profissionais da área de saúde atuaram intensamente em todo o país. Entre os leigos a solidariedade cresceu na mesma proporção que aumentou o número de enfermos e mortos devido à doença. Diversas pessoas ajudaram a angariar e a distribuir remédios e alimentos; prestaram auxílio aos gripados e seus familiares; e fizeram donativos às entidades (como a Cruz Vermelha Brasileira), que organizaram socorro aos doentes ${ }^{3}$.

Dia 21 de outubro de 1918, o jornal O Estado de S.Paulo publicou um resumo das considerações divulgadas pelo Serviço Sanitário do Estado para instruir a população no combate à moléstia. Os chamados Conselhos ao Povo foram reeditados várias semanas, em diversos jornais, e não só na cidade de São Paulo.

Evitar aglomerações, principalmente à noite.

Não fazer visitas.

Tomar cuidados higiênicos com o nariz e a garganta: inalações de vaselina mentolada, gargarejos com água e sal, com água iodada, com ácido cítrico, tanino e infusões contendo tanino, como folhas de goiabeira e outras.

Tomar, como preventivo, internamente, qualquer sal de quinino nas doses de 25 a 50 centigramas por dia, e de preferência no momento das refeições.

Evitar toda a fadiga ou excesso físico.

O doente, aos primeiros sintomas, deve ir para a cama, pois o repouso auxilia a cura e afasta as complicações e contágio. Não deve receber, absolutamente, nenhuma visita.

Evitar as causas de resfriamento, é de necessidade tanto para os sãos, como para os doentes e os convalescentes.

Às pessoas idosas devem aplicar-se com mais rigor ainda todos esses cuidados. (O Estado de S.Paulo, 21/10/1918, p.3)

Nas páginas dos jornais, os médicos repetiam que era preciso respeitar a "marcha natural da moléstia" ( $A$ Platéa, $22 / 10 / 1918$, p.6), isto é, as seis semanas que caracterizavam todo período epidêmico de gripe, a partir do primeiro caso da doença em uma região. Segundo os doutores, remédios ou vacina para curar a gripe ou imunizar contra a influenza (epidêmica ou não) não existiam. Mas, como indicavam os Conselhos ao Povo, alguns medicamentos poderiam auxiliar o tratamento e prevenção da gripe espanhola. Resultado: a corrida às farmácias foi desenfreada, preocupando médicos e autoridades governamentais, que determinaram medidas para controlar a venda e consumo exagerado de medicamentos (como o quinino). Preocupação semelhante acontece em 2009, pois apesar da ampla divulgação da inexistência de preventivos contra a gripe $A$, um grande número de pessoas têm recorrido às farmácias.

Em 1918, as cidades brasileiras foram parando a partir do início de outubro. As pessoas assistiram aos locais públicos (escolas, parques, teatros, cinemas, etc.) serem fechados; às reuniões religiosas serem reduzidas drasticamente, e aos enterros com acompanhamento a pé serem vedados. Beijos e abraços foram condenados, e cumprimentar as pessoas com aperto de mão passou a ser ato indesejado. A vida das cidades foi ganhando o compasso da gripe espanhola, com as pessoas mais e mais isoladas em suas casas na tentativa de não contrair a moléstia 4 . 
No Rio de Janeiro (com 914 mil habitantes) o número de gripados saltou de 440 , dia 10 de outubro, para cerca de 20 mil dois dias depois. Em São Paulo (com 528 mil moradores), o primeiro caso de gripe espanhola, oficialmente registrado, ocorreu dia 13 de outubro; dia 31 eram quase 30 mil os indivíduos que haviam contraído a "espanhola". Os mortos pela influenza epidêmica foram contabilizados no Brasil a partir de setembro (em Salvador), e no Rio de Janeiro as primeiras mortes pela moléstia foram divulgadas dia 13 de outubro (no final do período epidêmico seriam mais de 12 mil mortos). Entre belo-horizontinos, porto-alegrenses e paulistanos, os mortos pela "espanhola" foram contados a partir de 21 de outubro (em São Paulo o total de óbitos somou $1 \%$ da população) 5 .

0 aumento vertiginoso do número de enfermos e mortos gerou uma sensação de impotência generalizada, que fez o medo crescer imensamente. A notícia, publicada pelos jornais de São Paulo, da tentativa de suicídio de um operário ao supor estar com gripe espanhola, porque tinha dor de cabeça, dá uma noção do pavor que a doença despertava na população ( $A$ Gazeta, 23/10/1918, p.4).

A partir da segunda quinzena de novembro, para alívio das pessoas, a intensidade da gripe espanhola diminui gradualmente no Brasil e em várias partes do mundo, e o número de mortos pela epidemia também começou a decrescer. A explicação divulgada foi que o ciclo epidêmico da terrível influenza estava terminando. Difícil afirmar o total de gripados e de mortos pela gripe espanhola em todo o país, pois muitos lugares não fizeram registros. Em todo o mundo, foram, no mínimo, 600 milhões de enfermos e 20 milhões de mortos.

Hoje, no Brasil e no mundo, o medo paira. A possibilidade de uma reedição epidêmica similar a de 1918 existe, apesar dos novos conhecimentos científico-tecnológicos, do monitoramento internacional para tentar isolar doentes e possíveis focos de contaminação, e das pesquisas para a fabricação de uma vacina que ajudaria no combate à gripe A. Em 2009, como no início do século XX, a decifração completa da influenza (seu controle e prevenção efetiva) desafia médicos-pesquisadores de todo 0 mundo, e as ações de combate à gripe A lembram, e muito, o que foi realizado para combater a gripe espanhola em 1918. Uma triste coincidência: estudos feitos no início do século XXI indicaram que a influenza espanhola foi o resultado de uma combinação do vírus da gripe humana com o da gripe suína ${ }^{6}$.

Liane Maria Bertucci

Doutora em História da Universidade Estadual de Campinas - Unicamp.

Professora de História da Educação, no Departamento de Teoria e Fundamentos da Educação, da Universidade Federal do Paraná - UFPR, Curitiba, PR

\section{Correspondência}

Rua Machado de Assis, n 290 - apto. 302

Curitiba - PR

CEP: 80030-370

E-mail: liane@ufpr.br

Referências

1. Beveridge, WIB. Influenza: the last great plague. London: Heinemann; 1977.

2. Bertucci LM. Influenza, a medicina enferma. Campinas: Ed. Unicamp; 2004. p.90-9.

3. Bertucci LM. Influenza, a medicina enferma. Campinas: Ed. Unicamp; 2004. p.103-33.

4. Bertucci-Martins LM. Entre doutores e para os leigos: fragmentos do discurso médico na influenza de 1918. Hist Ciênc Saúde-Manguinhos. 2005;12:143-57.

5. Meyer CL, Teixeira JR. A grippe epidêmica no Brazil e especialmente em São Paulo. São Paulo: Casa Duprat; 1920.

6. Gibbs M, Amstrong J, Gibbs A. Recombination in the hemagglutinin gene of the 1918 'Spanish flu'. Science. 2001;293:1842-5. 